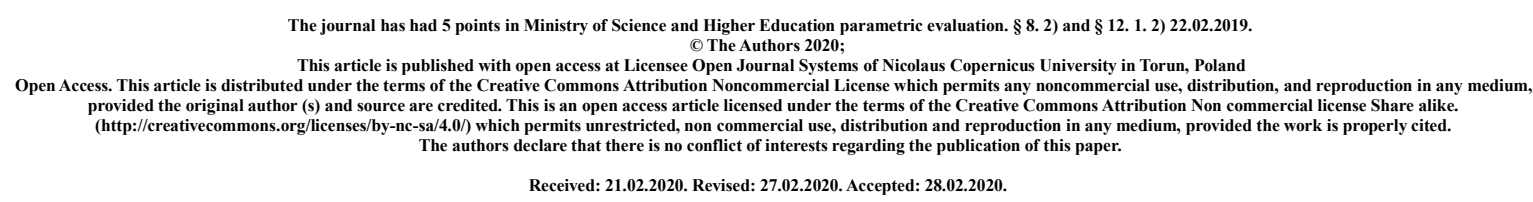

\title{
Tourist arrivals from Germany to Poland in the years 2000-2018
}

\author{
Krzysztof Parzych ${ }^{1}$, Rafal Gotowski ${ }^{2}$, Wiktoria Karczewska ${ }^{3}$
}

${ }^{1}$ Institute of Socio-Economical Geography and Tourism Pomeranian University in Słupsk

2 WSB University in Toruń

${ }^{3}$ State University of Applied Sciences in Konin

Key words: tourist space, German, tourist traffic

\begin{abstract}
This study addresses the issue of inbound tourism from Germany to Poland. The analysis of the issue was made on the basis of statistical data of the Local Data Bank of the Central Statistical Office of Poland based on data on the number of German tourists and the number of overnight stays granted to them in individual voivodships. In the years 2000, 2010, 2018.
\end{abstract}

\section{ADMISSION}

At the turn of the 1990s and the 21st century, changes in the spatial distribution of inbound tourism in Europe can be observed. Despite the dominant role played by Mediterranean countries and some Western European countries in incoming tourism, the role of Central and Eastern European countries has increased significantly. This phenomenon is undoubtedly associated with changes that have taken place in the political sphere and, consequently, also in the socio-economic sphere of Central and Eastern Europe. Also in Poland in recent years a quantitative increase in foreign inbound tourism can be observed. It is interesting: Are and to what extent the increase in the number of tourists accompanied by changes in the range of spatial impact of Poland as the destination destination of foreign tourists? 


\section{THE PURPOSE OF THE STUDY}

The issue of foreign inbound tourism is often addressed in the issues of tourism sciences research. Reports are regularly published by the Institute of Tourism in Warsaw, which constitute a comprehensive statistical analysis of the current state of inbound tourism to Poland (Bartoszewicz 2012). The subject of inbound tourism is also undertaken in the scope of visits of tourists from individual countries coming to Poland and in the context of the role of tourism in the socio-economic functioning of border areas (Meyer 2001, Ruszkowski 2014, Stolarska 2016, Więckowski 2010). A significant part of the studies concerns the historical analysis of inbound tourism in Poland (Kłysz 1963, Kłysz 2015, Kulczycki 1968). Some works have a regional character and relate to the arrivals of foreign tourists to individual tourist regions in Poland (Bosiacki 2012, Bergier 2007, Bergier, Soroka 2010; Stroik, Zajadacz 2007).

The aim of the study was a quantitative and spatial analysis of inbound tourism to Poland from Germany. The problem analysis was made in the spatial arrangement of individual voivodships in relation to the years 2000,2010,2018. The issue of inbound tourism from Germany to Poland has so far also been the subject of scientific research (Reed, Zajadacz 2017). In recent years, significant dynamics of foreign tourists arrivals to Poland has been observed. In 2018, a total of 7082231 arrivals of foreign tourists were recorded. In 2000, there were 3122030 , and in 2010 - 4134070 arrivals of foreign tourists. The highest rates of increase in the number of foreign arrivals in the regional system were recorded in the West Pomeranian voivodships: from 287172 to 821751 arrivals in 2018, Małopolskie - from 507329 in 2000 to 1504318 arrivals in 2018, in Dolnośląskie from 292159 to 697726 arrivals in 2018. Łódź from 66674 to 194876 in 2018. In total, an increase in the number of foreign arrivals was recorded in 15 voivodships (Fig. 1a, b, c). Only in the Warmian-Masurian Voivodeship a decrease in the number of arrivals of foreign tourists was recorded. Similarly, in the number of overnight stays provided to foreign tourists, there was a clear increase in the period 2010-2018. . In 2018, a total of 1,774,651 overnight stays were recorded, in 2010 it was $1,006,4628$ nights spent (Fig. 2a, b).

The highest increase in the number of overnight stays was recorded in the following voivodships: Zachodniopomorskie-3834298, Małopolskie-3652754, Mazowieckie-3143832, in Pomorskie voivodship-1542129 arrivals. The lowest values of the number of nights spent were recorded in the following voivodships: świętokrzyskie-105595, opolskie-108909, podlaskie-19920.

The highest increase in the number of overnight stays for foreign tourists was recorded in the following voivodships: Małopolskie: from 2135297 in 2010 to 3652754 overnight stays granted, in Mazowieckie from 1623229 in 2010 to 3143832 in 2018, Pomeranian from 640116 in 2000 to 1542129 in 2018, in West Pomerania from 2008067 in 2010 to 3 834298 in 2018. In total, 7082231 arrivals of foreign tourists to Poland in 2018, most tourists came from Germany (over $50 \%$ of arrivals), as well as from Great Britain and the Scandinavian countries (primarily from Norway and Sweden, Fig. 3a, b).

Similarly, in terms of the number of overnight stays provided to foreign tourists, the most overnight stays were given to tourists from Germany, Great Britain and the Scandinavian countries. (Fig. 4 a, b) In 2018, a total of 1836092 tourist arrivals from Germany to Poland were recorded. In the period 2000-2018 there was a systematic increase in the number of tourist arrivals from Germany to Poland, in 2000 it was 1052832 arrivals, in 2010 - 1128 378, in 2018 - 1836092 arrivals. In recent years, a clear dynamics of the increase in the number of tourist arrivals from Germany to Poland has been observed. 
The spatial distribution of tourist arrivals from Germany to Poland shows clear spatial preferences as compared to the analogous distribution regarding foreign tourist arrivals to Poland in total (Fig. 1d, e, f). In 2000, out of 1052832 German tourists (33.7\% of the total number of foreign tourists in Poland) who came to Poland the most were visited by Zachodniopomorskie -17.3\%, Dolnośląskie-15.3, Warmian-Masurian-15.9 and Pomorskie-10, $9 \%$ and Greater Poland- $10.3 \%$. Least. Tourist arrivals from Germany were concentrated in the following provinces: Podlasie, Świętokrzyskie and Lubelskie: less than 1.0\% of the total.

In subsequent years, there was a significant increase in the concentration of people arriving to the towns of West Pomeranian voivodships. In 2010, 1128837 arrivals of German tourists to Poland were recorded, which constituted $27.2 \%$ of the total number of foreign tourists in Poland this year.

There is a clear increase in the concentration of arrivals to the towns of the West Pomeranian Voivodeship, where tourists from Germany constituted 24.8\% of the total number of foreign tourists in Poland. In addition, $15.7 \%$ of arrivals were directed to the Lower Silesian Voivodship, about $9.8 \%$ to the Lesser Poland Voivodship, and about $8 \%$ each to the Masovian and Pomeranian Voivodships. The least arrivals of German tourists were recorded in the following provinces: Podlasie, Podkarpackie, Lubelskie and Świętokrzyskie.

In 2018, 1836092 tourists from Germany visited Poland, who constituted 25.9\% of the total foreign tourists in Poland. The increase in the concentration of visits of tourists from Germany in the West Pomeranian Voivodeship is even higher compared to the previous reference year. There were 688894 such arrivals, which accounted for $37.5 \%$ of all visits by German tourists to Poland. In addition, $14.7 \%$ of arrivals were directed to the Lower Silesian Voivodship, $8.4 \%$ to the Lesser Poland Voivodship, $8.1 \%$ to the Masovian Voivodship, and $6.7 \%$ to the Pomeranian Voivodship.

The smallest number of visits by German tourists was recorded in the following provinces: Podlasie, Lubelskie, Świętokrzyskie and Podkarpackie - less than $1.0 \%$ of total arrivals. In the analysis of visits of tourists from Germany, taking into account the number of overnight stays, similar trends of spatial concentration of stays appear. (Fig. 2 c, d) In 2010, foreign tourists in Poland were granted a total of 10064628 nights, of which the most in the following provinces: Małopolskie-21.2\% of the total, Zachodniopomorskie-20.0\%, Mazowieckie-16.1 and Dolnośląskie-10 1\%.

The least nights of accommodation were provided to foreign tourists in the following voivodships: Opolskie, Świętokrzyskie, Podlasie, Lubelskie - for less than 1.0\%. In 2018, German tourists were provided with 3828542 nights, which accounted for $38.0 \%$ of the total number of nights provided to foreign tourists.

In 2018, foreign tourists in Poland were allocated 17,742,651 nights, of which most in the following voivodships: Zachodniopomorskie: 3834298 (21.6\% of the total), Małopolskie-3 652754 (20.6\% of the total), Mazowieckie-3 143832 (17.7\% of total). In the total number of nights spent, German tourists were provided with 5,989,726 nights in 2018, which represented $33.7 \%$ of the total number.

In 2018, the largest number of overnight stays for German tourists was provided in the following voivodships: West Pomeranian: 3401391 nights $(56.8 \%$ of the total, Dolnośląskie - 682595 nights (11.4\% of the total). The least nights were German tourists in the following voivodeships: Lublin, Łódź, Opole , Podkarpackie and Podlasie: after less than $1.0 \%$ of the total number of overnight stays provided to foreign tourists.

An analysis of the spatial distribution of German tourists visiting Poland in 2010-2018 indicates certain trends emerging as inbound tourism from Germany to Poland. There is a systematic increase in the number of visits of German tourists to Poland in the years 20102018, at the same time the dynamics of this growth is lower compared to the dynamics of the increase in visits of foreign tourists to Poland. Overall, this is confirmed by the decrease in the 
share of visits of German tourists in the total number of tourists in 2010-2018.

There is a clear tendency in the spatial concentration of arrivals, especially in the West Pomeranian Voivodeship, where in 2010-2018, their share in the total number of foreign tourists increased from $17.3 \%$ to $37.5 \%$. This phenomenon should undoubtedly be associated with the growing share of German tourists' arrivals in the seaside spa municipalities of the Szczecin and Koszalin coastal regions: primarily Kołobrzeg, Świnoujście and Międzyzdroje and Dąbki.

It is noticeable in the cross-section of the years 2010-2018 the shortening of the average length of stay of a German tourist in Poland, especially for the most-visited voivodships: West Pomeranian and Lower Silesian. There is a visible increase in the number of German tourists in these voivodships, while the average length of stay is shortening. In the years 2000-2018, there were also changes in the length of stay of foreign tourists coming to Poland. For the analysis of the length of stay of foreign tourists in Poland, the average length of stay of foreign tourists in Poland was calculated (Table 1).

The average length of stay of a foreign tourist in Poland in 2010 was 2.43 days. The longest average stay of foreign tourists in Poland in 2010 was recorded in the following voivodships: Zachodniopomorskie-5.31 days, Świętokrzyskie-2.52, Warmian-Masurian - 2.5, Pomeranian - 2.46 and Dolnośląskie-2.45. The shortest average stays of foreign tourists were recorded in the following voivodships: Lubuskie-1.41, Lubelskie-1.43 and Podlaskie-1.5.

In 2018, a slight increase in the average length of stay of foreign tourists in Poland is observed. The value of the indicator increased to 2.51 days. The longest average lengths of stays abroad were recorded in the following voivodships: West Pomeranian: 4.67, Świętokrzyskie -2.86, Łódź-2.73, Pomeranian-2.69, and Warmian-Masurian and Lesser Poland - after 2.43 days. The shortest average stays were recorded in the following voivodships: Podlasie-1.37, Lubelskie-1.71, Lubuskie-1.84.

In 2010, the average length of stay of a German tourist in Poland was: 3.39 (Table 2). The longest average length of visits of foreign tourists in Poland was recorded in the following voivodships: Zachodniopomorskie-6.3, Dolnośląskie-3.21, Warmińsko-Mazurskie2.77, Łódź-2.59, and Pomeranian-2.52.

The shortest average lengths of stays of German tourists were observed in the following voivodships: Greater Poland-1.63, Podlasie-1.72, Lubelskie-1.79 and in Mazowieckie-1.8. In 2018, the average length of stay of a German tourist in Poland slightly decreased - from 3.39 in 2010 to 3.26 in 2018 (Table 2). On average, German tourists spent the longest stays in the voivodships of Lower Silesia: 4.94 days, Warmian-Masurian-2.72, Pomeranian-2.67, Małopolskie-2.53, Opolskie and Dolnośląskie-2.52. The shortest average length of stays was observed in the following voivodships: Wielkopolskie - 1.68, Mazowieckie - 1.7, Podlasie - 1.76 and Lubuskie $-1.82 \%$. In the years 2010-2018, the average length of stays in Poland is increasing and the spatial diversification of this phenomenon is increasing. At the same time, the average length of stay of German tourists is noticeable. This applies especially to well-established, preferred destinations for German tourists: West Pomeranian and Lower Silesian voivodships. 


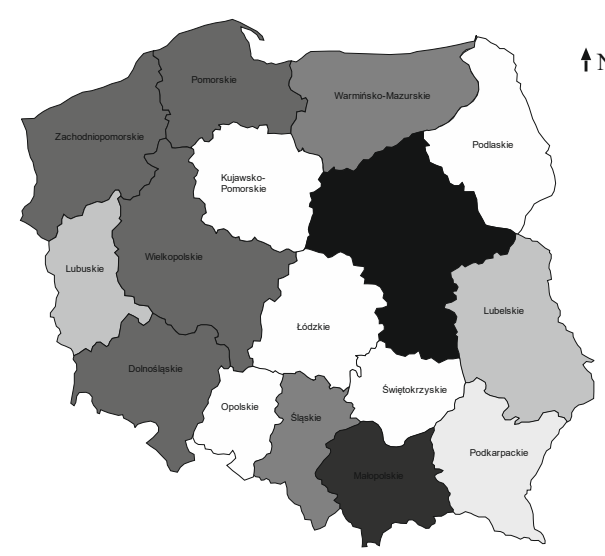

$\begin{array}{lllll}0 & 3 & 7 & 10 & 20 \%\end{array}$ and more

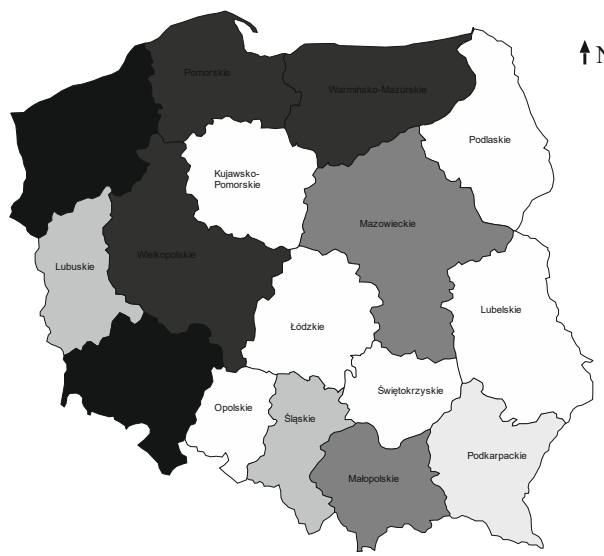

$\begin{array}{lllll}0 & 3 & 7 & 10 & 15 \%\end{array}$ and more

$\uparrow \mathrm{N}$

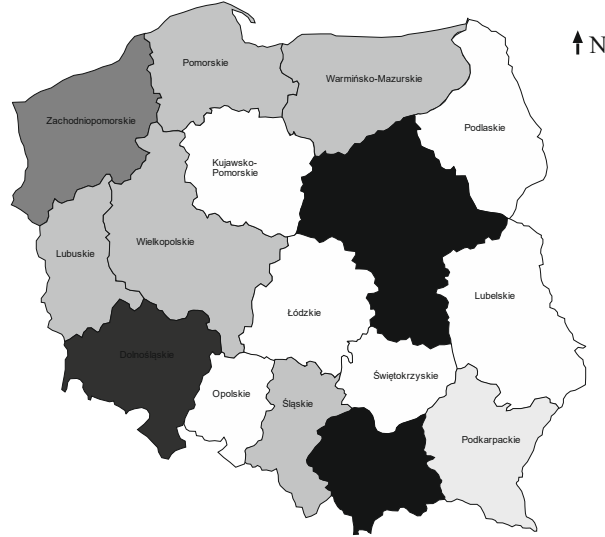

B

$\begin{array}{llllll}0 & 3 & 7 & 10 & 20 \% & \text { and more }\end{array}$

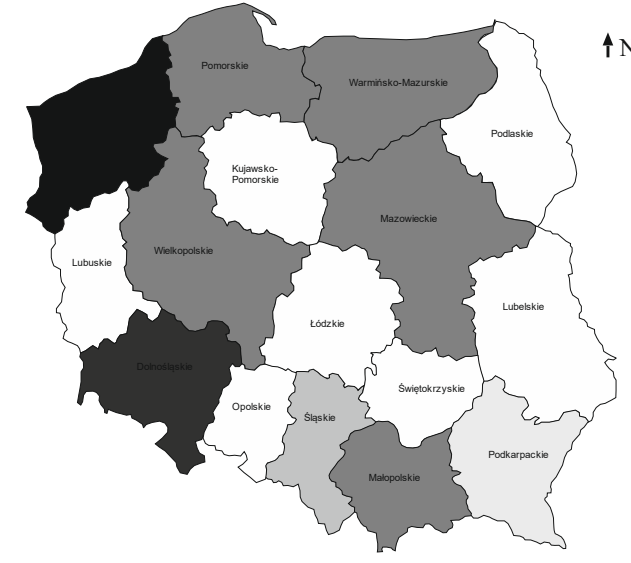

$\begin{array}{lllll}0 & 3 & 7 & 10 & 20 \%\end{array}$ and more

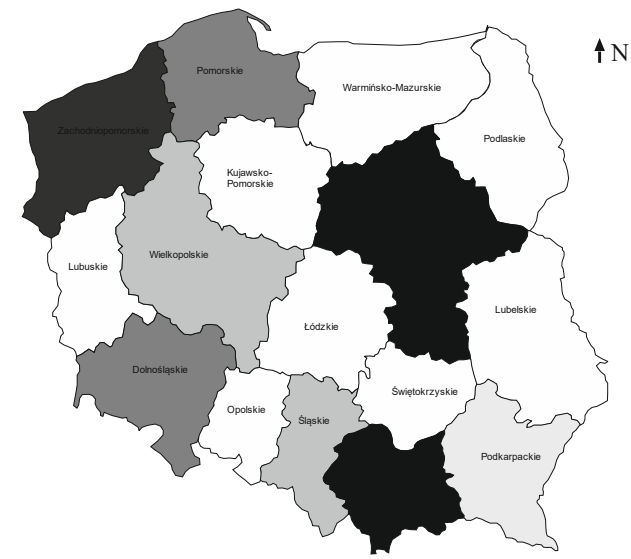

$\begin{array}{lllll}0 & 3 \quad 7 \quad 10 & 20 \% & \text { and more }\end{array}$

$N$

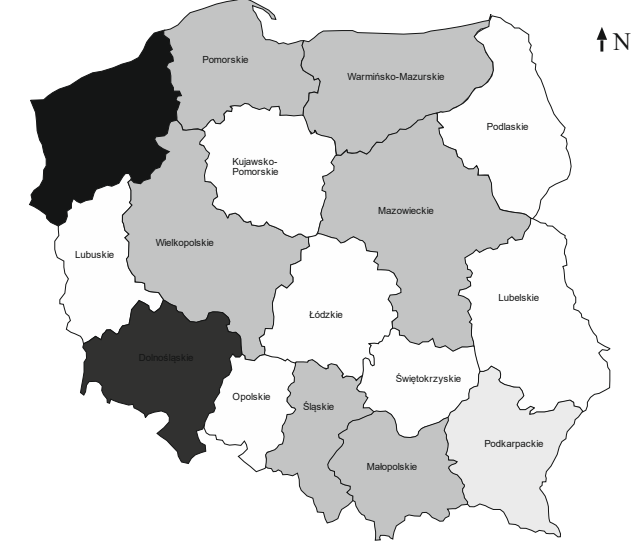

$\begin{array}{rrrrr}0 & 3 & 7 & 10 & 20 \% \\ \mathrm{~F} & & & \end{array}$

Fig. 1 a, b, cd, e, f Spatial distribution of tourist arrivals to Poland in 2010-2018, At foreign tourists in 2000, Bt foreign tourists in 2010, Cforeign tourists in 2018, D-tourists from Germany in 2010 of the year, E-tourists from Germany in 2010, F-tourists from Germany in 2018 

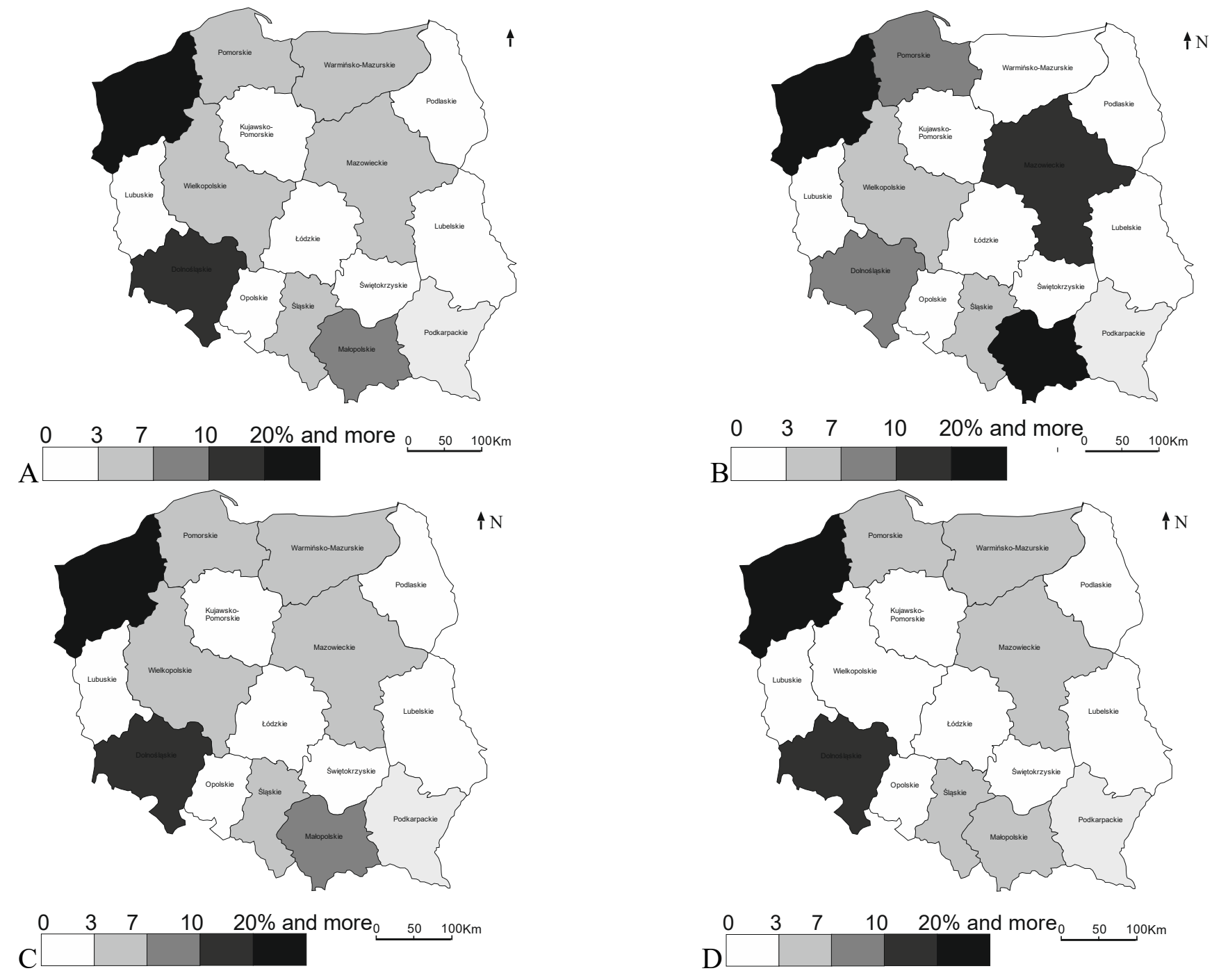

Fig 2 A,B,C,D Number of overnight stays provided to foreign tourists in Poland in 2010-2018, A-Total foreign tourists in 2010, B-Total foreign tourists in 2018, C-German tourists in 2010,D- German tourists in 2018 

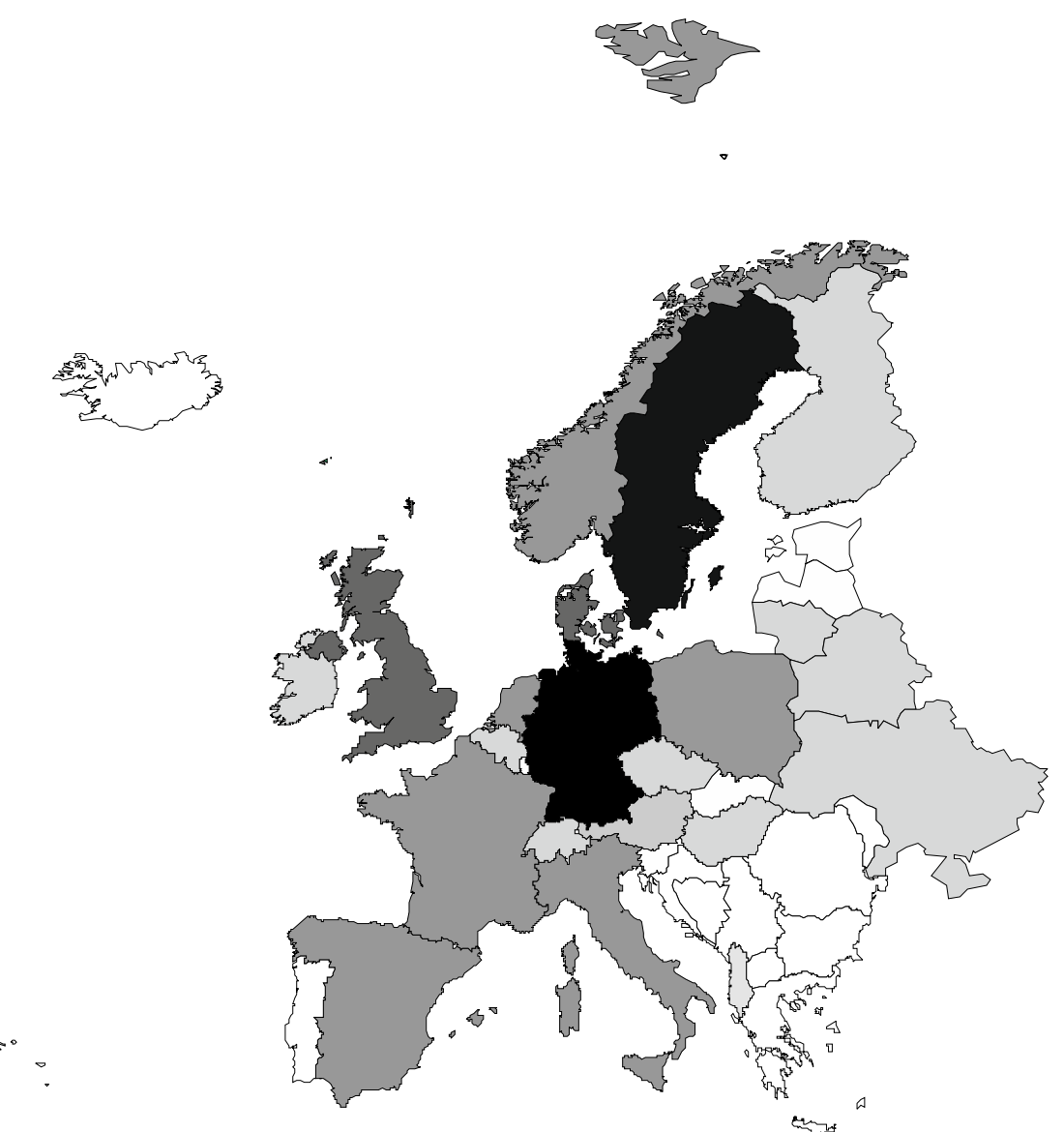

$0 \quad 100050001000025000$ and more

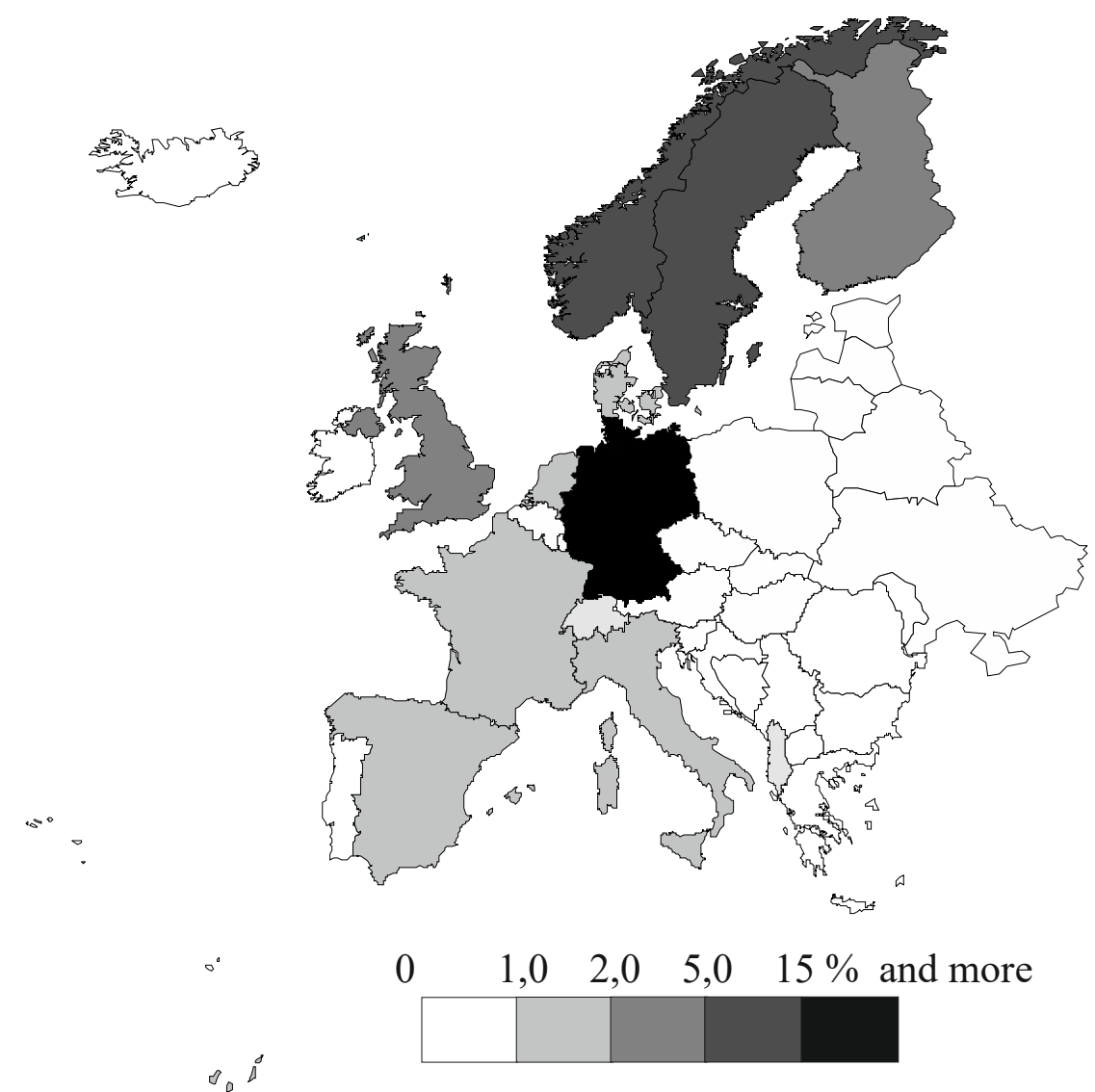

A $\theta i$

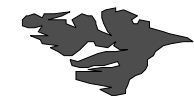

Fig 3A,B Spatial distribution of arrivals of foreign tourists Polish house in 2018, A-number of arrivals, B-percentage share in the total number of arrivals 


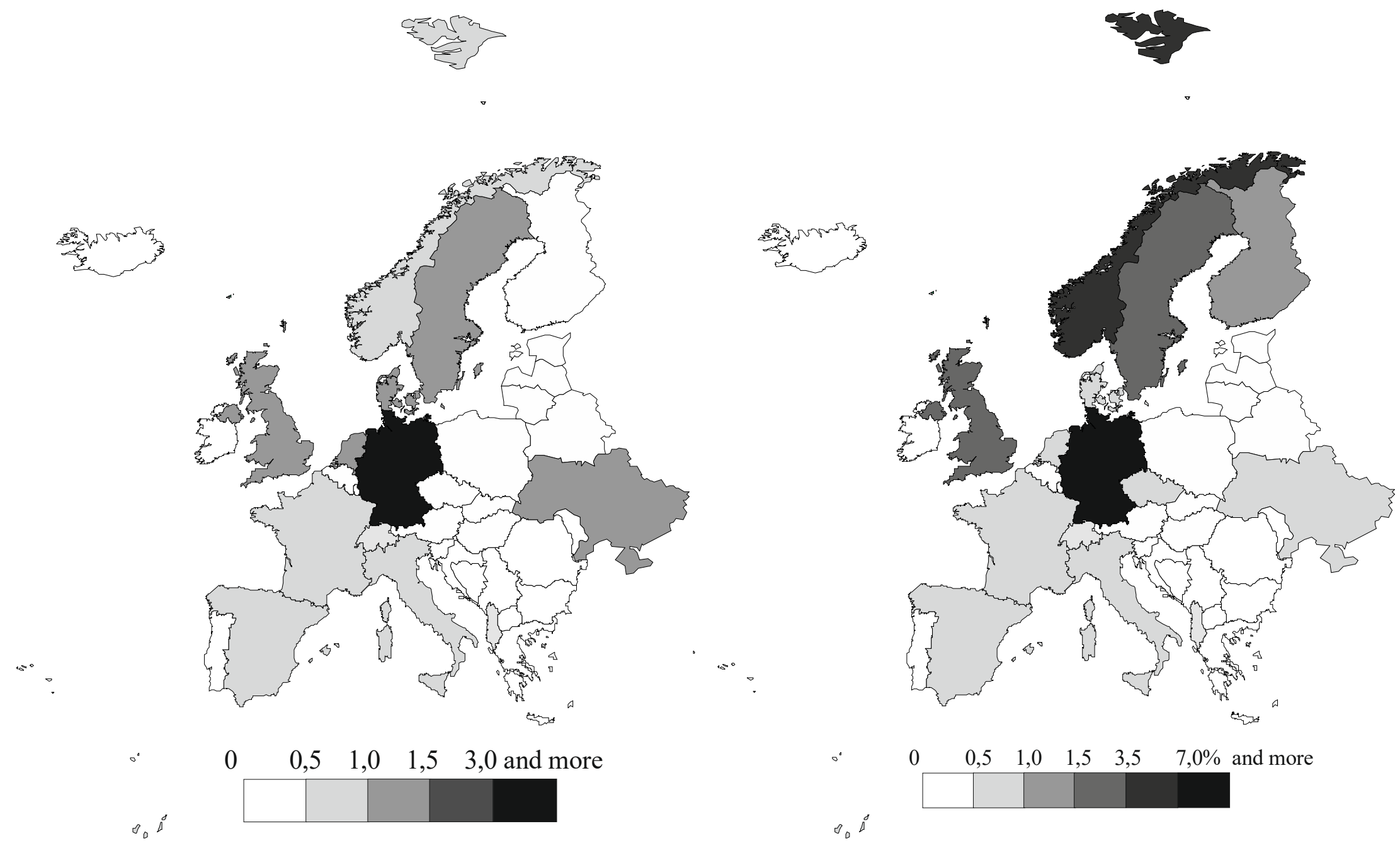

Fig. 4A,B Spatial distribution of overnight stays for foreign tourists coming to Poland in 2018, A-total number of arrivals, B-percentage share in the total number of arrivals 
Table. 1 Te average length of stay of foreign tourists in Poland in the years 2010-2018

\begin{tabular}{|c|c|c|c|}
\hline Voivodship & 2010 & Voivodship & 2018 \\
\hline Lubuskie & 1,41 & Podlaskie & 1,37 \\
\hline Lubelskie & 1,43 & Lubelskie & 1,71 \\
\hline Podlaskie & 1,50 & Lubuskie & 1,84 \\
\hline Mazowieckie & 1,81 & Podkarpackie & 1,93 \\
\hline Wielkopolskie & 1,89 & Mazowieckie & 1,98 \\
\hline Kujawsko-Pomorskie & 2,23 & Opolskie & 2,00 \\
\hline Podkarpackie & 2,26 & Dolnośląskie & 2,13 \\
\hline Opolskie & 2,29 & Wielkopolskie & 2,13 \\
\hline Śląskie & 2,37 & Śląskie & 2,29 \\
\hline Małopolskie & 2,38 & Kujawsko-Pomorskie & 2,40 \\
\hline Łódzkie & 2,39 & Małopolskie & 2,43 \\
\hline Dolnośląskie & 2,45 & Warmińsko-Mazurskie & 2,43 \\
\hline Pomorskie & 2,46 & Pomorskie & 2,69 \\
\hline Warmińsko-Mazurskie & 2,50 & Łódzkie & 2,73 \\
\hline Świętokrzyskie & 2,52 & Świętokrzyskie & 2,86 \\
\hline Zachodniopomorskie & 5,31 & Zachodniopomorskie & 4,67 \\
\hline Average & 2,43 & Average & 2,51 \\
\hline
\end{tabular}

Table.2 The verage length of stay of tourists from Germany in Poland in the years 2010-2018

\begin{tabular}{|l|c|l|c|}
\hline Voivodship & $\mathbf{2 0 1 0}$ & Voivodship & $\mathbf{2 0 1 8}$ \\
\hline Wielkopolskie & 1,63 & Wielkopolskie & 1,68 \\
\hline Podlaskie & 1,72 & Mazowieckie & 1,70 \\
\hline Lubelskie & 1,79 & Podlaskie & 1,76 \\
\hline Mazowieckie & 1,80 & Lubuskie & 1,82 \\
\hline Kujawsko-Pomorskie & 1,86 & Łódzkie & 1,96 \\
\hline Lubuskie & 1,91 & Kujawsko-Pomorskie & 1,97 \\
\hline Podkarpackie & 2,24 & Lubelskie & 2,11 \\
\hline Świętokrzyskie & 2,43 & Śląskie & 2,14 \\
\hline Małopolskie & 2,43 & Podkarpackie & 2,15 \\
\hline Śląskie & 2,48 & Świętokrzyskie & 2,44 \\
\hline Opolskie & 2,50 & Dolnośląskie & 2,52 \\
\hline Pomorskie & 2,52 & Opolskie & 2,52 \\
\hline Łódzkie & 2,59 & Małopolskie & 2,53 \\
\hline Warmińsko-Mazurskie & 2,77 & Pomorskie & 2,67 \\
\hline Dolnośląskie & 3,21 & Warmińsko-Mazurskie & 2,72 \\
\hline Zachodniopomorskie & 6,30 & Zachodniopomorskie & 4,94 \\
\hline Average & 3,39 & Average & 3,26 \\
\hline
\end{tabular}

\section{CONCLUSIONS}

The spatial distribution of inbound tourism to Poland is marked by the dominance of tourist arrivals from Germany. This is due to the close proximity, high attractiveness of Poland as the destination country of arrivals, dynamic development of service infrastructure and general infrastructure in recent years. An important role considering the importance of the "sentimental factor", which is confirmed by the preferred destinations of German tourists to Polish. In the spatial distribution of foreign inbound tourism with Germany in the years 2010- 
2018, a steady increase in the number of visits of tourist tourists in Poland is noticeable, while its dynamics in relation to the dynamics of arrivals to meetings with other user groups is ended. There is a clear tendency of concentration of arrivals to the towns of the West Pomeranian and Lower Silesian Voivodships (in 2018, in both these voivodships, almost $60 \%$ of all visits to travels with Germany in Poland were concentrated), as well as a decrease in the number of other voivodships among the preferred destinations of arrival for main tourists coming to Poland. The figures are given for the decrease in the average length of German tourists' travel in Poland, even in the traditionally preferred destinations of tourists. The phenomenon of more frequent and then shorter visits is observed. Among the most-dominant Polish tourist voivodships most frequently visited by German tourists: Podkarpackie, Podlasie, Lubelskie, Świętokrzyskie, which must be strictly associated with distances and in order to connect with available communication for tourists from Germany.

\section{Summary}

The article deals with the issue of inbound tourism from Germany to Poland. The analysis of the problem was made against the background of general data on foreign inbound tourism to Poland on a regional basis, of individual voivodships in Poland. As source material, data on the number of arrivals and the number of overnight stays for German tourists were used against the background of the number of arrivals and the number of overnight stays provided to foreign tourists in Poland in the years 2000, 2010, 2018. In addition, an analysis was made of the average length of stay of German tourists compared to the total of foreign tourists in Poland in 2010 and 2018. The results indicate the dominant role played by inbound tourists from Germany to Poland compared to other foreign tourists. At the same time, a decrease in the dynamics of German tourists' arrivals to Poland in the analyzed period is observed, as well as an increase in the spatial concentration of visits in the West Pomeranian and Lower Silesian voivodships a simultaneous decrease in the average length of stay of a German tourist in Poland against the background of the average length of total visits of foreign tourists.

\section{BIBLIOGRAPHY}

- Bartoszewicz S.,2013, Zagraniczna turystyka przyjazdowa do Polski, Instytut Turystyki, Szkoła Główna Turystyki i rekreacji, ss.93

- Bergier J., 2007, Rozwój turystyki przyjazdowej do województwa lubelskiego w latach 2001-2016 przesłanką strategii rozwoju, [w::]J Bergier, M. Stelmach, (red), Kierunki rozwoju turystyki w województwie lubelskim, PWSZ w Białej Podlaskiej 
- Bergier J., Soroka A., 2010, Tendencje w turystyce zagranicznej do województwa lubelskiego, Barometr regionalny 2 (20), s.35-40

- Bosiacki S., 2012, Motywy przyjazdów oraz wydatki turystów w Poznaniu w 2010 roku, Ekonomiczne Problemy Usług nr 84, 11-22, Koszalin

- Kłysz P., 1963: Zagraniczny ruch turystyczny w Polsce w latach 1956-1962. Gorzów Wlkp. [maszynopis]. Kowalczyk A., 2002: Geografia turyzmu. Wyd. Nauk. PWN, Warszawa.

- Kłysz P., 2015 Z historii zagranicznego ruchu turystycznego w Polsce, Badania fizjograficzne, R. I - Seria A - Geografia fizyczna (A61), s. 181-190

- Kulczycki Z., 1968: Zarys historii turystyki w Polsce. Sport i Turystyka, Warszawa.

- Meyer B., 2001, Znaczenie turystyki transgranicznej w obszarach przygranicznych, w: Sektor turystyczny w społeczeństwie informacyjnym, red. A. Panasiuk, Fundacja Uniwersytetu Szczecińskiego, Szczecin 2001.

- Stolarska A., 2016, Rozwój turystyki zagranicznej w wybranych krajach UE, Zeszyty Naukowe Szkoły Głównej Gospodarstwa Wiejskiego Ekonomika i Organizacja Gospodarki Żywnościowej nr 116, 2016: 67-79

- Stroik E., 2016, Rola Niemiec w turystyce światowej w latach 2005-2014 w świetle raportów Światowej Organizacji Turystyki, w: Uwarunkowania i plany rozwoju turysty-ki, t. 17: Organizacja i rozwój rynku usług turystycznych, red. Z. Młynarczyk, A. Zajadacz, Poznań: Bogucki Wydawnictwo Naukowe

- Ruszkowski J., 2014,Turystyka transgraniczna w Polsce jako narzędzie budowania współpracy na pograniczu wschodnim, Ekonomiczne Problemy Turystyki nr 3(27), Zeszyty Naukowe nr 807,

- Stroik E., Zajadacz A.,2017, Międzypokoleniowe aspekty turystyki przyjazdowej mieszkańców Niemiec do Poznania,Studia Periegetica nr 3(19)/2, s.47-65

- Więckowski M.,2010, Turystyka na obszarach przygranicznych Polski, Wyd. PAN IGiPZ, Warszawa 2010. 